\title{
Between Experimentalism and Anachronism - the Road to the Abolishment of the European Commission of the Danube
}

The European Commission of the Danube is a necessary evil and [...] it must be preserved [...]. But it should work according to instructions from the Romanian state, in the interest of the Romanian economy.

CONSTANTIN D. BUȘILĂ, 1936

Romania's entry into the First World War in August 1916 put a stop to a long period of peace and prosperity for the Maritime Danube, along which shipping was governed by the European Commission of the Danube. With an extraordinary international legal status inscribed in the Peace Treaties of Paris (1856) and Berlin (1878) and in other documents agreed within Europe's Concert of Powers in $1858,1866,1871$ and 1883 , the Commission had managed, as presented throughout this volume, to instil a security regime for international shipping along the Maritime Danube through its hydraulic works and rulemaking. In the early twentieth century this international organisation was the subject of much scholarly attention from the proponents of liberal internationalism. Some of them viewed the Commission as a noteworthy example of 'successful international administration,' ${ }^{1}$ which could be replicated around the globe. The status of the Danube was thoroughly discussed at the Paris Peace Congress, where decision-makers preserved the Commission as the institutional organ that was to regulate shipping along the Maritime Danube. But the solutions reached in Paris in 1919-1921 were far from the expectations of institutional globalists and represented a step back when compared to the nineteenth-century status of the IO. This marked the beginnings of a long period in which the Commission became an object in the geopolitical realignment of the Lower Danube during the interwar period, in the Second World War and in the early post-war years.

1 Cecil Delisle Burns, International Politics (London 1920), 150. 
This chapter aims to summarise the main political events that shaped the Commission during the first half of the twentieth century. It will not focus on aspects related to the organisation's hydraulic works and rulemaking, which continued along the same general lines as before 1916, though with increasing opposition from Romania, eager to restore its hurt territorial sovereignty. Eventually, the Commission was abolished and a new international organ, the Danube Commission, representative of post-war southeastern European realities, was established in the summer of 1948, exactly when the United Nations started organising seminars on 'world understanding' and the progress of internationalism. ${ }^{2}$

In concert with the previous nine chapters of this volume, this will hopefully allow interested readers to compare and contrast the status of Danubian river commissions in the nineteenth and twentieth centuries and to assess how much a technopolitical organ switched back and forth between its technical and political components or between its 'innovative' and 'anachronical' character.

\section{The Limits of Neutrality - the Commission during the First World War}

The spectre of war overshadowed the Commission's bright prospects. The years 1910 and 1911 were two of the best for its finances, with incomes of more than 3 million francs a year and annual surpluses of about 800,00o francs. The Balkans Wars in 1912-1913 reduced the organisation's revenues and affected its hydraulic and administrative works after the mobilisation of the Romanian army. With the Great War looming on the horizon, the eight commissioners met at an extraordinary session in July 1914 and reaffirmed the Commission's neutrality in the event of military conflict. ${ }^{3}$

Romania did not join the war in 1914 and the Commission could claim a position of apparent neutrality and relative diplomatic immunity. Despite minor arguments between delegates from belligerent parties, the autumn and spring sessions of 1914 and 1915 continued with discussions of the organisation's daily business: the technical state of the Sulina mouth, the Commission's

2 Glenda Sluga, Internationalism in the Age of Nationalism (Philadelphia 2013), 1.

3 Iulian Cârțană and Ilie Seftiuc, Dunărea în istoria poporului roman (Bucharest 1972), 112; Richard Frucht, Dunărea Noastră. Romania, the Great Powers, and the Danube Question. 19141921 (Boulder and New York 1982), 29. 
budget, its statistical bulletins and the activity of the hospital. ${ }^{4}$ The closure of the Turkish Straits, however, after the Ottoman Empire joined the war in October 1914, diminished international navigation throughout the Black Sea basin, including along the Maritime Danube. Facing increasing financial shortages, the Commission suspended most of its hydraulic works. In 1915, at the commissioners' request, European governments subsidised the organisation, and Romania granted it several advances in $1915^{-1916}$ to allow it to pay salaries and carry out urgent works. ${ }^{5}$

The Commission's bureaucratic staff was directly affected by the general mobilisation in several European countries, which reduced available employees in all services. Growing divisions between nationals of belligerent countries were accompanied by gossip, rumours and fear. The Romanian secret police paid due attention to the strategic value of the mouths of the Danube and closely watched the foreign visitors who could threaten the security of this vital waterway. ${ }^{6}$

After political and military preparations, Romania joined the war in August 1916 on the side of the Entente, which could better secure its aspirations of union with the Romanians of Austria-Hungary. Commissioners of enemy states were asked to leave the country, while employees were interned in concentration camps. All the Commission's resources were to be used to advance the Entente's military cause. ${ }^{7}$

Romania's military campaign was brief and disastrous. By the end of November 1916, only three months after its triumphant declaration of war, the regions of Dobrudja and Wallachia (or two thirds of pre-war Romania) were occupied by troops of the Central Powers, and the Romanian royal family and government sought refuge in Iași, in the country's still free region of Moldavia. The port of Brăila in Wallachia was taken by the enemy, while Galați remained, ten miles downstream the Danube, in 'free Romania'. With the Commission's main headquarters in Galați threatened by an imminent attack, Duiliu Zamfirescu, Romania's commissioner, took part of the organisation's assets and archives

4 The National Archives of Romania, Galați Branch, Protocols of the European Commission of the Danube (hereafter PECD), Protocols 869-878 (24 October-25 November 1914) and 879-888 (15-29 May 1915); Frucht, Dunărea Noastră, 30; Ștefan Stanciu, România și Comisia Europeană a Dunării. Diplomație. Suveranitate. Cooperare internațională (Galați 2002), 186-187.

5 La Commission Europèene du Danube et son œuvre de 1856 à 1931 (Paris 1931), 493.

6 Ion Rîșnoveanu, 'Acțiuni de spionaj la Sulina la începutul Primului Război Mondial,' Analele Universității Ovidius din Constanța - Seria Istorie 5 (2008): 53-64.

7 Frucht, Dunărea Noastră, 34. 
to Odessa, where he and Piotr Kartamishev, Russia's delegate, sought refuge. ${ }^{8}$ From early 1917, the Carolus Primus, the Commission's inspection yacht, served as the IO's seat from its mooring post in the harbour of Odessa. The Danish resident engineer, Eugene Magnussen, and the Romanian maritime commissioner remained in Sulina, while Russian warships controlled shipping in the Danube Delta. Russian authorities tried to keep the river navigable for securing communications with their troops quartered on the Moldavian front, ${ }^{9}$ but by late 1917 the Bolshevik revolution had let the Maritime Danube fall into the hands of the Quadruple Alliance.

According to a convention signed by the victors, hydraulic works along the Danube were to be coordinated by the 'Zentral Transport Leitung' (ZTL), an Austrian-Hungarian company established to nurture the former hydroimperial claims of the Double Monarchy. Its agent at the Maritime Danube was Fran Vilfan, a former chief of service in the Commission as Captain of the Port of Sulina, who had been arrested by the Romanians in $1916 .{ }^{10}$ The Treaty of Bucharest, the separate peace treaty signed by Romania and the Central Powers in May 1918, referred to the general principles that were to reorganise navigation on the Danube. ${ }^{11} \mathrm{~A}$ 'Commission of the Mouths of the Danube' would take over the powers, privileges and obligations of the Commission downstream of Brăila. It was to consist 'of delegates from riparian states to the Danube or the European shore of the Black Sea only', thus including Romania and the four allied Central Powers, which secured large economic and military benefits in Romanian territory for themselves. At the same time, the German and Austrian-Hungarian cabinets provided funds for resuming technical works on the Danube and making use of its waterway for military and economic purposes. The war ended in November 1918 without completing the much-needed engineering projects along the Maritime Danube. As Europe began to reclaim a sense of order, the Commission was reset in an attempt to instil the same in the Danube Delta and restore the full navigability of the Maritime Danube. ${ }^{12}$

8 The headquarters were bombed and most of the archives were lost: Stanciu, România și Comisia Europeană a Dunării, 188.

$9 \quad$ Spiridon G. Focas, The Lower Danube River: In the Southeastern European Political and Economic Complex from Antiquity to the Conference of Belgrade of 1948 (Boulder and New York 1987), 428-430.

10 Frucht, Dunărea Noastră, 40-44; Focas, The Lower Danube, 430-434.

11 Constantin I. Băicoianu, Dunărea văzută prin prizma tractatului din București: o lămurire a concepției germane despre pace, de dreptate (Bucharest 1921).

12 Joseph P. Chamberlain, The Regime of the International Rivers: Danube and Rhine (New York 1923), 127-128. 


\section{Internationalism and Exceptionalism - the Danube Regime at the Paris Peace Congress}

At the Paris Peace Congress, Romania aimed to change the Danube regime and instate its full territorial sovereignty over the Maritime Danube. The best option was to abolish the Commission and unify the entire river under the jurisdiction of a single IO, on the model of the Central Commission for the Navigation of the Rhine. ${ }^{13}$

Eventually, after complicated negotiations between the victors, transboundary rivers in Europe ended with a unified regime, except for the Danube. The Versailles Treaty stipulated that the Danube was internationalised from Ulm to the Black Sea, and free navigation was extended along the entire navigable waterway, including Danube's main tributaries. However, the river course was divided between two river commissions: the International Commission of the Danube, with jurisdiction over the entire navigable section of Danube (except for the Maritime Danube), and the Commission, with authority along the Maritime Danube. The International Commission of the Danube was to include delegates from all riparian countries, plus the three non-riparian European victorious powers (France, Great Britain and Italy). The Commission provisionally consisted of the delegates from Romania and the three nonriparian victors. The definitive regime of the Danube would be decided at a future conference, where delegates from all countries with interests in Danubian navigation were to take part, while defeated states could only send delegates to assist. Finally, the League of Nations was the superior legal forum for settling disputes between the two river commissions and riparian states. ${ }^{14}$

In 1920, the Barcelona Conference on the Permanent Organisation of Communication and Transit, Railways, Navigation and Ports assembled delegates from 41 states in a much more multilateral environment. Several resolutions and conventions were concluded, which laid down the general rules applicable to all international rivers and other specific elements for regulating international transportation infrastructure. ${ }^{15}$ In relation to transboundary waterways, each contracting state had to secure, in its own territorial jurisdiction,

13 Details in Stanciu, 'Problema Dunării în dezbaterile Conferinței de Pace de la Paris (19191920),' Danubius 18 (2001): 49-82 and Arthur Tuluș, 'Problema Dunării la Conferința de Pace de la Paris și în perioada imediat următoare,' Analele Universității Dunărea de Jos din Galați. Istorie 7 (2008): 175-182.

14 Relevant articles in Gordon Sherman, 'International Organization of the Danube under the Peace Treaties,' American Journal of International Law 17.3 (1923): 457-459.

15 H. Fortuin, 'The Regime of Navigable Waterways of International Concern and the Statute of Barcelona,' Netherlands International Law Review 7.2 (1960): 125-143. 
the free exercise of navigation for any other contracting power. At the same time, each riparian state could freely use its waterway as it best fitted its interests: for cabotage, it reserved the right for national authorities to transport cargo and people between its own ports, while states could establish and enforce laws, policing, customs, public health, emigration and immigration regulations, as well as ban goods for export or import. The Barcelona Convention established the right of riparian states to regulate navigation and supervise its application. There was however a derogation from this rule for the transboundary waterways managed by international commissions in which non-riparian states were included. ${ }^{16}$ The Danube fell into this special category.

The decision on the Danube regime was taken at another conference hosted in Paris in 1920-1921. Romanian delegates hoped to diminish the prerogatives of the Commission and prevent the organisation from doing hydraulic works in its territorial waters and river ports. They also wanted to be granted the right to draw up navigation and policing regulations and to appoint officers to apply them. There were several disputes between riparian and non-riparian states concerning both river commissions, so the International Commission of the Danube ended up having less powers than the Commission. The Convention for the Definitive Statute of the Danube was signed in Paris on 23 July 1921. The freedom of navigation and equality of flags were guaranteed along the entire river, including on its navigable tributaries. The Danube was divided into two sections, regulated by the two IOs: the fluvial section by the International Commission of the Danube and the Maritime Danube by the Commission. The Commission preserved its pre-war rights, prerogatives and immunities along the Maritime Danube, as well as its provisional membership structure, though

any European state that justifies in future sufficient commercial, maritime and European interests at the Mouths of the Danube, will be allowed, upon its request, to be represented in the Commission by a unanimous decision taken by the governments that are themselves represented.

The powers of the Commission could only end by an arrangement concluded between all member states. ${ }^{17}$

16 Carmen Atanasiu, Problema suveranității României la Dunăre și "Navigația Fluvială Română": 1919-1945 (Bucharest 2003), 95 .

17 'Convention Instituting the Definitive Statute of the Danube,' American Journal of International Law 17.1 (1923): 13-27; Frucht, Dunărea Noastră, 75-111; Focas, The Lower Danube, 453-494. 
To Otto Popper, the first secretary of the International Commission of the Danube, the 1921 statute was 'a somewhat unsatisfactory compromise between broad conceptions and narrow-mindedness.' ${ }^{18}$ The presence of the three nonriverain states and their powerful shipping companies ${ }^{19}$ stimulated the economic environment, although it took some time to turn the watercourse into the transportation backbone of successor states along the Middle Danube. All in all, during most of the interwar period the work of the two IOs was met with 'considerable success, ${ }^{20}$ which had a lot to do with a 'fourth great power present' along the entire Danube: 'the spirit of modern technical science, represented by many outstanding personalities' who engaged upon important hydraulic projects that further transformed the river into an accessible stream for international navigation. ${ }^{21}$

In Romania, the Definitive Status was received with open antipathy. The Romanian authorities were trying to prove that the country had the financial means and technical abilities to manage the navigable waterway on its own and kept demanding the abolition of this 'anachronical organ'. Nicolae Titulescu, Romania's permanent representative to the League of Nations in Geneva, and a promoter of this nationalist internationalism, voiced the irritation of many Romanians: except for the Danube, 'no international river in the world is subject to the supervision of two commissions. ${ }^{22}$

'The Most Unbelievable Anachronism' - Revisionism along the Lower Danube

One of the disputes between Romania and the Commission concerned jurisdiction over the Galați-Brăila section of the Danube. The 1883 London Convention placed it under the Commission's authority, but Romania rejected this decision to which it was not party, while the IO did not push the delicate matter further in case it damaged relations with its host state (Chapter 8). The thorny issue returned in the 1920s, and a solution was sought in front of the Permanent

18 Otto Popper, 'The International Regime of the Danube,' The Geographical Journal 102.5 (1943): 244 .

19 Alice Teichova and Penelope Ratcliffe, 'British Interests in Danube Navigation after 1918,' Business History 27.3 (1985): 283-300.

20 Stephen Gorove, 'Internationalization of the Danube: A Lesson in History,' Journal of Public Law 8 (1959): 135 .

21 Popper, 'The International Regime': 244.

22 Nicolae Titulescu, Discursuri (Bucharest 1967), 547. More on the 'Statut Définitif and Romanian Public Opinion' in Frucht, Dunărea Noastră, 112-123. 
International Court of Justice in The Hague. ${ }^{23}$ Lengthy debates followed, and eventually partial agreements were reached in 1930 and 1933, with the two parties agreeing to refrain from further escalating the diplomatic conflict. ${ }^{24}$

However, such compromises failed to satisfy Romanian hardliners, who were looking for solutions to diminish the Commission's powers and hopefully disband it altogether. At the Montreux Straits Conference in 1936, Titulescu, Romania's Foreign Minister at the time, supported Turkey's full jurisdiction over the Turkish Straits. Titulescu believed that it was high time for Romania to suppress the Commission, which was 'the most unbelievable anachronism, the most inadmissible [form of] foreign territorial control, responding internationally least to the goals for which it was created'. To him (and other nationalists in Romania), this was not about revising treaties, but about unifying a disjointed river regime. Titulescu did not overtly contest the international character of the Danube, but claimed the restoration of Romania's rights, which were severely injured by a parasitical organisation. ${ }^{25}$

However, several Romanian statesmen rejected his 'revisionist' position, believing that the abolition or erosion of the Commission's powers was a serious mistake in that international context. With Nazi Germany's denouncement of the waterways clauses of the Versailles Treaty relative to the internationalisation of certain 'German' rivers (including the Danube), Romania's objectives shifted to a milder view of the Commission: the IO came to be regarded as a political bulwark for Romania's sovereignty, even for its territorial integrity. ${ }^{26}$ Titulescu was soon replaced from office, and his successors acted to preserve the Commission. Romanian engineer and politician Constantin D. Bușilă

23 Mémoire du Gouvernement roumain dans la question du Danube (Bucharest 1925).

24 Focas, The Lower Danube, 495-514; Atanasiu, 'Activitatea României pentru desființarea Comisiei Europene a Dunării,' Analele Dobrogei, new series 6.1 (2000): 281-292; Agnieszka Kastory and Bogdan Zieliński, 'The Diplomatic Dispute over the Rights of the European Commission of the Danube during the Interwar Period,' Politeja 10.1 (2008): 165-174.

25 More on the period in Stanciu, 'Poziția României față de Marile Puteri în problema navigației pe Dunărea Maritimă în perioada premergătoare celui de-al Doilea Război Mondial, Danubius 21 (2003): 79-100; on Titulescu and the Commission: Ardeleanu, 'Nicolae Titulescu și Comisia Europeană a Dunării. Câteva ecouri pe marginea interviului lui N. Titulescu din cotidianul “Le Temps" - iulie 1936,' Danubius 21 (2003): 67-77; Tuluș, 'Nicolae Titulescu's Position on the International Regime of Waterways. The International Straits Commission versus the European Commission of the Danube,' Danubius 35.2 (2017): 117-132.

26 Tuluș, Dunărea maritimă între Aranjamentul de la Sinaia și Acordul de la Belgrad: (19381948) (Galați 2008), 36-54. 
clearly expressed the new Romanian view on the Commission, as quoted in the motto of this chapter. ${ }^{27}$

Things became even more complicated with changes in the political geography of Danubian Europe. Romanian statesmen considered that it was in the country's best interests to stick to the Commission and to the 'principle of internationalisation with the participation of the Great Powers'. Another Romanian juridical expert, George Sofronie, believed that

from a legal and moral point of view, the European Commission is an anachronism. I would sympathise with its dissolution, but I see that it is not a happy solution at this time for Romania's interests. Certain expansionist tendencies make it necessary to have the Great Powers present at the mouths of the Danube. These states can exert an unbiased influence on the selfish tendencies of riparian states along the rest of the river. ${ }^{28}$

The western powers were also trying to appease Romania's frustration and gave up some of the Commission's attributions that violated the host state's sovereignty. A preliminary agreement amongst member states was concluded in 1938 to amend the status of the Danube by cancelling the application of Article 53 of the 1878 Berlin Treaty (which established full independence for the Commission in relation to territorial power). ${ }^{29}$ Nazi Germany also increased its pressure to join the Commission and had the support of its ally, Italy. Romania thus urged for the organisation of a conference of its current membership before Germany's imminent admission into the IO.

Delegates from France, Great Britain and Romania took part in the Sinaia Conference in August 1938. Romania's Foreign Minister, Nicolae PetrescuComnen, criticised the Commission for its violations of national sovereignty, but also referred to its important political role on the Lower Danube. The 'Sinaia Arrangement' put an end to the supranational powers which the Commission and its agents had been exercising over the Maritime Danube. Sulina lost its international character and returned under Romania's full territorial jurisdiction. Romania took over the Inspectorate of Navigation, the corps of pilots, the sanitary service, and the organisation's movable and immovable goods. The Commission was to draft regulations for policing and navigation, which were to be applied by Romania. Romanians were to be employed gradually in the offices of the Commission's bureaucratic and technocratic services.

27 Quoted in ibid., 51.

28 Ibid., 53.

29 Focas, The Lower Danube, 520. 
An autonomous service, called the Maritime Danube Directorate (MDD), was to draft and execute hydraulic works, levy taxes and spend the income to the benefit of navigation. The MDD's projects were vetted by a committee of European engineers, appointed by the Commission. Further arrangements were made to decide on the juridical situation, immunities and rights of the Commission's remaining staff. ${ }^{30}$

The Italian government accepted the arrangement, its official position following consultations with its German ally. Eventually, in March 1939, in connection with the western powers' 'appeasement' policy, Germany was accepted as a full member state in the Commission, which had become a political organisation used by Europe's imperial powers to advance their political and military interests.

\section{Between the Nazis and the Soviets - the Commission in the Second World War}

After the outbreak of the Second World War, riparian states along the Danube vowed to preserve the river's neutrality. At the Lower Danube Romania tried the same, although it faced huge pressure from both belligerent camps. In October 1939, the Commission held its ordinary session, and all five commissioners participated. Although rivalries made themselves clearly visible, the organisation functioned normally and discussed the regular issues for an autumn session: its financial situation, payment of staff and placement of the Commission's funds. An extraordinary session was held in February 1940, when the five delegates analysed the IO's financial status. In May 1940, the Commission met once again and decided to prolong the river's neutrality. ${ }^{31}$

Larger military and geopolitical changes greatly affected the situation of the Commission and that of its institutional sibling, the International Commission of the Danube. In June 1940, the Soviet Union reannexed Bessarabia from Romania and thus returned as a riparian state to the Maritime Danube. In August 1940, at a favourable point in its military actions against the western

30 Protocoles de la Conférence tenue à Sinaia du 8 au 18 août 1938 pour la modification du régime du Danube. Arrangement de Sinaia du 18 août 1938 relatif à l'exercice des pouvoirs de la Commission Européenne du Danube. Accord de Bucarest du 1er mars 1939 (Galați 1939). Details in: Focas, The Lower Danube, 520-531; Kastory, 'La Conférence de Sinaia consacrée à la Commission Européenne du Danube (août 1938), Revue Roumaine d'Histoire 42.1-4 (2003): 293-304; Tuluș, Dunărea maritimă, 79-124.

31 Stanciu, România și Comisia Europeană a Dunării, 309-313; Tuluș, Dunărea maritimă, $125^{-136 .}$ 
powers, Germany requested the dissolution of the International Commission of the Danube, an organisation from which it had previously withdrawn its delegate. A Danubian Conference took place in Vienna in September 1940, where Germany, Hungary, Italy, Romania, Slovakia and Yugoslavia participated. This formalised German hydro-hegemony along the internationalised Danube, between Bratislava and Brăila, in a newly established 'Council of the Fluvial Danube', while the section between Ulm and Bratislava remained exclusively under German jurisdiction. ${ }^{32}$

At the Maritime Danube, however, Nazi Germany faced a much stronger competitor - the USSR. In September 1940, the Soviet government requested the dissolution of the Commission and 'the establishment of a single commission of riparian states, whose jurisdiction should extend from the mouths of the Danube upstream to Bratislava'. In the Danube Delta a joint Romanian-Soviet administration was to coordinate navigation along the Romanian part of the area. In October-December 1940, Bucharest hosted a Danubian Conference which was to decide on the new status of the Maritime Danube. Delegates from Germany, Italy, the Soviet Union and Romania attended the negotiations. Romania relied on support from Berlin and Rome and successfully rejected Soviet pretensions. A new conference was organised in February 1941, with similar results. Negotiations were suspended in March 1941, with the Axis powers in expectation of their war against Soviet Russia. ${ }^{33}$

The Commission continued to exist formally, but the political and military situation in Europe turned the entire Danube, including its lower section, into a highway for the transportation of German military equipment. After its initial military successes on the Eastern Front, Nazi Germany called for a new Danubian Conference, which was held in Bucharest in November 1942. The German delegate proposed abolishing the Commission and including a German official in the administration of the Maritime Danube. However, the Romanians delayed their compliance for as long as possible, and managed to maintain control over their national river section. ${ }^{34}$

32 Focas, The Lower Danube, 542-543; Ottmar Trașcă, 'Problema Dunării în contextul relațiilor româno-germane din toamna anului 1940,' in: Vasile Docea (ed.), Relațiii româno-germane. Studii istorice (Cluj-Napoca 2003): 101-120; Alexandru Ghișa, “'Laffaire du Danube" et l'européanité de la Roumanie,' Danubius 32 (2014): 244-245.

33 Focas, The Lower Danube, 544-546; Stanciu, România și Comisia Europeană a Dunării, 321-326; Tulus, Dunărea maritimă, 159-175.

34 Tuluș, 'Dunărea Maritimă în anii celui de-al Doilea Război Mondial (1941-1945),' Analele Universității Dunărea de Jos din Galați. Istorie 5 (2006): 155-193. 
'The Door Was Open to Come in; the Same Door Is Open to Go out' - the Danube under Soviet Hegemony

By the end of the war, the western powers tried to restore the interwar river regime. This, however, depended on the Soviet Union, which controlled the entire Middle and Lower Danube. In several statements, Soviet diplomats made it clear that they had a reorganisation of the Danube's regime based on the 1815 Vienna principles in mind, understood as reserving membership in river commissions to riparian states. ${ }^{35}$

The United States led the coalition of states which demanded 'the greatest possible freedom of trade and navigation' along the Danube, regarded as 'the artery of all Central Europe'. Two opposing views made themselves clear during the negotiations for the conclusion of the peace treaties with Romania, Bulgaria and Hungary. An identical clause relating to the Danube was included in the Paris Peace Treaty, signed on 10 February 1947:

Navigation on the Danube will be free and open to citizens, merchant vessels and goods of all states, on an equal footing, in terms of port and navigation duties and conditions to which commercial navigation is subjected. The above provisions do not apply to the cabotage between ports of the same state. ${ }^{36}$

The rifts of the Cold War drew the two camps further apart and the future organisation of Danubian navigation was turned into a symbolic battle between them. This was to be discussed at a conference scheduled to take place in Belgrade. As Stephen Gorove justly noted, the conference provided 'an opportunity to test Russian good faith at an international gathering in which, for the first time, the Soviet Union and its satellites would command a clear majority'. For the Soviet Union, it was the perfect occasion to create 'a semblance of legality' for its political and economic control over the Middle and Lower Danube. ${ }^{37}$

The Danubian Conference convened on 30 July 1948. Delegates from ten countries participated, and the result was clear given the new political realities in southeastern Europe. Andrey Vyshinsky was factotum, and had no problem in steering Moscow's satellite states towards the expected conclusion:

35 Focas, The Lower Danube, 586-588.

36 Cited in Joseph L. Kunz, 'The Danube Regime and the Belgrade Conference,' American Journal of International Law 43.1 (1949): 107.

37 Stephen Gorove, Law and Politics of the Danube: an Interdisciplinary Study (The Hague 1964), 124-125. 
on 18 August 1948, the Belgrade Convention received seven votes (Bulgaria, Czechoslovakia, Hungary, Romania, the Soviet Union, Ukraine and Yugoslavia) against one - that of the American delegate, Cavendish Cannon. The representatives from France and Great Britain had left the conference room and refused to vote on a document that they claimed failed to comply with international law. There were several issues on which the western powers tried to have a say, but they all ended with a Soviet imposition. The principle of freedom of navigation was included in the document, but cabotage was reserved to riparian states. A new organ, the Danube Commission, was to supervise navigation along the entire river. It consisted of commissioners from each signatory riparian state, among whom a president, vice-president and secretary were elected for a period of three years. The Danube Commission would have a permanent secretariat and all necessary services, and its staff would be recruited from citizens of member states. Each state was responsible for hydraulic works in its own territorial waters, while more complex engineering was conducted in coordination with the Danube Commission. Two special bilateral administrations (for the Iron Gates and the Danube Delta) were to improve navigation in the respective passages. Through an additional protocol, the 1921 Definitive Status was abolished, and the goods belonging to the Commission were transferred to the Romanian-Soviet Special Administration of the Maritime Danube. ${ }^{38}$

Vyshinsky was not shy in making clear who the new master was. In fact, Moscow's control was so strict that the participants proposed no amendments, 'not even the change of a comma', to the Soviet preliminary proposal. Cannon tried to defend the western view, though the brutal reply came with little diplomatic gentleness: "The door was open to come in; the same door is open to go out, if it is what you wish.' ${ }^{39}$ Cannon stayed, to showcase the new type of relations within the communist block and with the western world.

Under the slogan 'The Danube for Danubian states', the Soviet Union accomplished larger strategic aims in central and southeastern Europe. To a Soviet author, the Belgrade Convention embodied 'the generally accepted principles and norms of international law' and was 'an expression of the peace-loving foreign policy of the Danubian democratic states'. The agreement expressed the desire of the Danubian peoples 'for peace and international cooperation' and created all necessary conditions for riparian countries to cooperate amongst themselves and with other states, 'based on the concept of the possibility of

38 Stanley M. Max, 'Cold War on the Danube: The Belgrade Conference of 1948 and AngloAmerican Efforts to Reinternationalize the River,' Diplomatic History 7.1 (1983): 57-78; Focas, The Lower Danube, 595-630; Kastory, 'La conférence de Belgrade de 1948 et la nouvelle organisation de la navigation danubienne,' Revue Roumaine d'Histoire, 43.1-4 (2004): 289-302; Tuluș, Dunărea maritimă, 257-278.

John C. Campbell, 'Diplomacy on the Danube,' Foreign Affairs 27.2 (1949): 322. 
peaceful coexistence between two social and economic systems subjected to mutual respect for the sovereign rights of states' ${ }^{40}$ However, despite such propaganda, the Soviet Union had its wider plans of economic control, which were already underway through joint shipping and trading companies in which the USSR had the ruling vote. ${ }^{41}$

\section{The Danube Commission - Inclusion and Exclusion}

The Danube Commission continued to be hosted by the Commission's palace in Galați, but in 1954 it moved to Budapest, better placed midway along the Danube and friendlier for commissioners chosen from among diplomats in Hungary. During the communist period, the Danube Commission was a reliable thermometer of political relations within the communist bloc and beyond it. During the period of conflict between Stalin and Tito, Moscow refused to involve Yugoslavia into the Danube Commission's management (controlled by Director General Grigoriy Morozov), while the Yugoslavs delayed installing, until 1953, the Joint Administration of the Iron Gates. ${ }^{42}$ At the same time, the USSR intensively supported the construction of the Danube-Black Sea Canal and forced the Romanian state to spend enormous sums on completing it. ${ }^{43}$

In the first phase of the Cold War, the Danube Commission did not cooperate with the UN and its specialised agencies. Gradually, the unification of navigation, customs and sanitary regulations of riparian states favoured commercial exchanges within the communist bloc. Additionally, Moscow limited the Danube's connection to the outside world through its lack of interest in the maintenance of the Sulina Canal. This branch, placed under a special Romanian-Soviet administration, was badly maintained, while the Soviet Union attached great importance to the development of its own waterway along the Chilia branch. ${ }^{44}$ By the mid-1950s, with the abolition of mixed shipping societies, the USSR's exclusive control over Danubian navigation came to an end, and its authority continued to be exercised in more subtle ways. ${ }^{45}$

40 P.G. Fandikov, Mezhdunarodno-pravovoŭ rezhim Dunaîa: istoricheskiŭ ocherk (Moscow 1955), 21.

41 CAM, 'The Régime of the Danube,' The World Today 4 (9 September 1948): 368-375.

42 David T. Cattell, 'The Politics of the Danube Commission under Soviet Control,' American Slavic and East European Review $19 \cdot 3$ (1960): 384-386.

43 Nicolas Spulber, 'The Danube-Black Sea Canal and the Russian Control over the Danube,' Economic Geography 30.3 (1954): 236-245.

44 Cattell, 'The Politics': $387-388$. Tamás Hardi, 'Danube Developments against the Backdrop of History and Geopolitics,' Der Donauraum 52.2 (2012): 269-276.

45 Mioara Anton, 'The End of Hegemony. The Joint Romanian-Soviet Commission and the Danube Question,' Romanian Naval Museum Yearbook 7 (2004): 196-202. 
In response to the dissolution of the Commission in 1948, the authorities in London and Paris re-established the IO in exile, in Rome. Representatives from France, Great Britain, Italy and Greece gathered to defend the rights of former employees and seized the Commission's gold deposited in western banks. ${ }^{46}$

By the late 1950s, the 'communist' Danube gradually started to be opened for trade relations with the West, firstly with Austria and Federal Germany. From June 1957, the two 'capitalist' states sent their representatives to participate as experts at the plenary sessions of the Danube Commission and at the works of its various standing subcommittees ${ }^{47}$ After an unsuccessful first attempt, ${ }^{48}$ Austria joined the Danube Commission in January 196o. Bilateral agreements were signed between riparian governments for the improvement of navigation and the use of the river for joint economic projects. ${ }^{49}$ Plans for large-scale irrigation and electricity production, in which Soviet and American models of river development were used, aimed to increase the economic prosperity of the area. ${ }^{50}$

The end of the Cold War was a tumultuous period for Danubian Europe. The German unification, the dissolution of the Soviet Union and the wars in Yugoslavia changed its membership structure, which is, at the same time an image of new Europe, as it is of Cold War age Europe. With a charter decided by Stalin's envoy in 1948, the Danube Commission includes eleven states: the ten Danubian republics and the Russian Federation, which has remained a member state, although Russia is no longer a riparian country. Seven member states of the Danube Commission are part of the European Union, and the other three have strong ties with the European bloc. Ten other states with economic interests in Danubian Europe and the Black Sea area have an observer status in the Danube Commission, so the prospects of turning the Danube into a 'highway' of prosperity for bordering nations seem to have more chance than ever before.

46 Focas, The Lower Danube, 629.

47 Catell, 'The Politics': 392-393.

48 Kastory, 'L'Autriche et ses premières tentatives pendant la période de l'après-guerre (1955-1956) pour une adhésion à la Commission Danubienne (d'après les documents britanniques et français),' Revue Roumaine d'Histoire 44.1-4 (2005): 279-292.

49 Guido G. Weigend, 'The Danube River: an Emerging Regional Bond,' Geoforum 6.2 (1975): 151-161; Guido Thiemeyer, 'Die Integration der Donau-Schifffahrt als Problem der europäischen Zeitgeschichte,' Archiv für Sozialgeschichte 49 (2009): 303-318.

5o Vincent Lagendijk, 'Divided Development: Post-War Ideas on River Utilisation and Their Influence on the Development of the Danube,' International History Review 37.1 (2015): $80-98$. 